\title{
Four novel strains of cellulolytic symbiotic bacteria isolated and characterized from GI tract of marine fishes of various feeding habits
}

\author{
Asha Augustine*, Imelda Joseph \\ Central Marine Fisheries Research Institute, Post Box 1603, Ernakulam North P.O., Cochin 682018, Kerala, India
}

\section{A R T I C L E I N F O}

\section{Keywords:}

Marine symbiotic bacteria

16S rRNA gene

Phylogenetic tree

Cellulose

\begin{abstract}
A B S T R A C T
Selected marine fishes with different feeding habits were screened for the presence of symbiotic cellulolytic bacteria in their gut. Four cellulolytic species of symbiotic bacteria were isolated from GI tract of marine fishes namely Carangoides praeustus, Filimanus similis, Sardinella longiceps and Sillago sihama. The strains were identified after polyphasic phenotypic and genotypic (16S rRNA gene) characterization as Bacillus subtilis strain TCPC1, Vibrio alginolyticus strain CFSS2C2, Pseudomonas stutzeri strain KSLS4C3 and Klebsiella oxytoca strain MSSC4. (Genbank Accession nos.: JN710380, JN710378, JN710377, JN712301).The results indicated the presence of cellulolytic bacteria in GI tract of marine fishes of carnivorous, phytoplanktivorous and omnivorous feeding habits. Cellulolytic activity was the maximum for B. subtilis strain TCPC1 $\left(0.45 \mathrm{mg}\right.$ glucose $\left.\mathrm{ml}^{-1}\right)$ and $V$. algi-

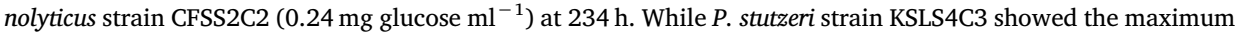
utilization ( $0.22 \mathrm{mg}$ glucose $\mathrm{ml}^{-1}$ ) from 240 to $258 \mathrm{~h}$. K. oxytoca strain MSSC4 $\left(0.47 \mathrm{mg}\right.$ glucose $\left.\mathrm{ml}^{-1}\right)$ showed three peaks during the study. The maximum rate of cellulose utilization was shown by $P$. stutzeri strain KSLS4C3

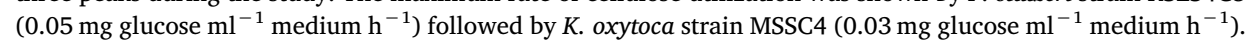

\section{Introduction}

Algae consumed by marine fishes contain more complex and different carbohydrates than vascular plants. In addition to difference in secondary metabolites, digestion is achieved in a differing ionic environment. Neither has attracted much attention by researchers as yet (Krogdahl et al., 2005). Herbivorous fishes often exhibit higher carbohydrase activities, apparently to digest the storage carbohydrates of macroalgae, which can contain up to $50 \%$ carbohydrate (Horn et al., 1986), whereas carnivorous fishes frequently show higher proteolytic enzyme activities, to digest their high-protein animal diets (Fish, 1960; Cockson and Bourne, 1972). Studies on both marine (Moran and Clements, 2002) and freshwater (Drewe et al., 2004) fishes that undergo ontogenetic dietary shifts revealed that changes in digestive enzyme activities reflect the dietary changes of the fishes. Assessment of the substrate degrading ability of gut microflora is important in understanding the nutrition and physiology of the host organism and may help in formulating appropriate feeds. However, the precise nutritional role played by these bacteria is not clearly understood (Tanu et al., 2011).

Cellulase activity has been observed in several fish species indicating that fish may be able to utilize cellulose and similar fibrous carbohydrates (Chakrabarti et al., 1995). Whether the observed cellulase activities are of endogenous or microbial origin is under debate (Lindsay and Harris, 1980; Chiu and Benitez, 1981).

Reports on the existence of cellulase activity in the digestive system of fish are rare and moreover are conflicting with contradictory result. As pointed out by Luczkovich and Stellwag (1993), much of the controversy concerning the source of cellulose activity in the gut of fishes has been due to the inability to isolate cellulolytic microorganisms. Fish (1951), Barrington (1957) and Yokoi and Yasumasu (1964) believed that fish do not posses endogenous cellulase.Shcherbina and Kazlawlene (1971) indicated the presence of microbial cellulase in the posterior portion of digestive tract of carp. Lindsay and Harris (1980) showed cellulase activity in the digestive tract of fish and suggested the source of cellulose activity from the microbial population,although they discarded the idea of maintenance of stable cellulolytic microflora in fish. Lesel et al. (1986) reported cellulolytic flora in grass carp. Das and Tripathi (1991) assumed the cellulase-producing bacteria as a part of persistent intestinal flora in fish. The presence of considerable cellulolytic bacterial population has been observed in fish digestive tracts including those of carnivorous murrels by Kar and Ghosh (2008).

The absence of proof of endogenous cellulases in fishes leads to speculations about the role of symbiotic bacteria especially in case of phytoplanktivores. Among the three major groups of marine microalgae, chlorophyceae contain a significant proportion of cellulose in the

\footnotetext{
* Corresponding author.

E-mail address: dr.ashaaugustine@gmail.com (A. Augustine).
} 
wall. Therefore, while cellulose digestion is important in some herbivorous fishes that eat green algae and sea grass, it is non applicable to the vast majority of marine fishes (Mackie et al., 1996).

Studies on the diversity and role of individual microbes in the fish gut have been hampered by the lack of adequate methodologies. For a given microbial species to be identified by means of their phenotypic features, this species has to be cultivated. To date, the gut microflora of fish has been traditionally investigated by culture dependent methods by isolating organisms from intestinal material and culturing and subsequently analysing them. The recent advent of molecular methodologies has greatly aided in the analysis of the bacteria and the findings from culture-based methods have been supplemented with molecular techniques that are based on the 16S rRNA gene (Zoetendal et al., 2004; Romero and Navarrete, 2006; Yang et al., 2007).

Bioinformatics provides software tools to deal with the vast amount of data (over 36 billions base pairs and 30 millions sequences alone at genbank) (Ramu et al., 2003). One of these tools is BLAST (Basic Local Alignment Search Tool), which searches for patches of similarity using similarity scoring matrices. BLASTn is used to compare a DNA sequence with DNA sequences in the database. It returns a list of best matches with their bit score and E-value. The Sequences can be aligned across their entire length (global alignment) or only in certain regions (local alignment). With the aid of multiple sequence alignments, biologists are able to study the sequence patterns conserved through evolution and the ancestral relationships between different organisms. The most widely used programs for global multiple sequence alignment are from the Clustal series of programs. The culture dependent methods and identification of the fish microbiota based on phenotypic and biochemical key characteristics is still the mainstay for studies on the microbial ecology of the gut of fishes. Marine fishes of India were not yet explored for potential cellulolytic strains of symbiotic bacteria. Cellulases are industrially important and identification of novel sources always help in improving the technology.

Cellulase activity has been observed in several fish species indicating that fish may be able to utilize cellulose and similar fibrous carbohydrates (Chakrabarti et al., 1995). Whether the observed cellulase activities are of endogenous or microbial origin is under debate (Lindsay and Harris, 1980; Chiu and Benitez, 1981). In a study of digestive enzymes in grass carp Ctenopharyngodon idella, cellulase was observed both in hepatopancreas and intestine and the dietary cellulose level affected the activities significantly (Das and Tripathi, 1991). The fact that cellulase activity was reduced to approximately one third when the antibiotic tetracycline had been added to the diet, indicates that microorganisms may supply an important part of the cellulolytic activity in the intestinal tract of fish. The residual activity measured in the presence of the antibiotic, indicate that a fraction of the activity may be of endogenous origin (Das and Tripathi, 1991). However, because of the abundance of antibiotic resistance, there is the distinct possibility that tetracycline-resistant organisms may account for the remaining activity (Krogdahl et al., 2005).

Reports on the existence of cellulase activity in the digestive system of fish are rare and moreover are conflicting with contradictory result. As pointed out by Luczkovich and Stellwag (1993), much of the controversy concerning the source of cellulose activity in the gut of fishes has been due to the inability to isolate cellulolytic microorganisms. Fish (1951), Barrington (1957) and Yokoi and Yasumasu (1964) believed that fish do not posses endogenous cellulase. Shcherbina and Kazlawlene (1971) indicated the presence of microbial cellulase in the posterior portion of digestive tract of carp. Lindsay and Harris (1980) showed cellulase activity in the digestive tract of fish and suggested the source of cellulose activity from the microbial population, although they discarded the idea of maintenance of stable cellulolytic microflora in fish. Lesel et al. (1986) reported cellulolytic flora in grass carp. Das and Tripathi (1991) assumed the cellulase-producing bacteria as a part of persistent intestinal flora in fish. The presence of considerable cellulolytic bacterial population has been observed in fish digestive tracts including those of carnivorous murrels by Kar and Ghosh (2008).

The absence of proof of endogenous cellulases in fishes leads to speculations about the role of symbiotic bacteria especially in case of herbivores. Among the three major groups of marine microalgae, chlorophyceae contain a significant proportion of cellulose in the wall. Therefore, while cellulose digestion is important in some herbivorous fishes that eat green algae and sea grass, it is non applicable to the vast majority of marine fishes (Mackie et al., 1996). Symbiotic bacteria have developed sophisticated mechanisms for the regulation of both catabolic and anabolic pathways. Generally, they do not synthesize degradative (catabolic) enzymes unless the substrates for these enzymes are present in their environment. Bacterial cells shut down biosynthetic (anabolic) pathways when the end product is not needed or is readily obtained by uptake from the environment (Todar, 2011).

Applications of cellulases and hemicellulases in the feed industry have received considerable attention because of their potential to improve feed value and performance of animals (Dhiman et al., 2002). Pretreatment of agricultural silage and grain feed by cellulases or xylanases can improve its nutritional value (Godfrey and West, 1996). The enzymes can also eliminate antinutritional factors present in the feed grains, degrade certain feed constituents to improve the nutritional value, and provide supplementary digestive enzymes such as proteases, amylases, and glucanases (Kuhad et al., 2011). One of the important applications is supplementing diets of farm animals with cellulases to improve feed utilization and animal performance by enhancing fiber degradation. Dairy cows fed with forage treated with a cellulase enzyme preparation ate more feed and produced 5-25\% more milk (Murad and Azzaz, 2010). If these enzymes can be recombinantly produced on mass or produced in situ by the bacterial strains naturally encoding them, the cost of hydrolysis for the production of biofuels can be decreased by reducing the need for production of multiple enzymes for efficient hydrolysis. Isolation and characterization of cellulase-producing bacteria will continue to be an important aspect of biofuel research (Maki et al., 2009). Microbial enzymes have enormous advantage of being produced in large quantities by established fermentation techniques. Considerable efforts have been devoted to the selection of microorganisms via sophisticated screening techniques for the production of enzymes with new physiological/physical properties and tolerance to extreme conditions used in the industrial processes (e.g. temperature, salts and $\mathrm{pH}$ ). The marine environment has proven to be a rich source of both biological and chemical diversity (Pomponi, 1999).

Marine microorganisms have recently emerged as a potent source for the isolation of industrial enzymes (Chandrasekaran, 1997) as marine bacterial enzymes have several advantages for industrial utilization (Ventosa and Neito, 1995). The optimum activity of marine bacterial enzymes usually occurs at high salinity, making these enzymes utilizable in many harsh industrial processes, where the concentrated salt solutions used would otherwise inhibit many enzymatic transformations. In addition, most marine bacterial enzymes are considerably thermotolerant, remaining stable at room temperature over long periods. The surfaces and internal spaces of marine organisms are more nutrient rich than seawater and most sediments, thus they would likely to be a unique niche for the isolation of diverse assemblages of bacteria. These associated bacteria are a potential source of biologically active compounds of low molecular weight (Fenical, 1993, Kobayashi and Masami,1993, Trischman et al., 1994). On the other hand proteins, especially enzymes, have been largely neglected (Mohapatra et al., 2003).

\section{Materials and methods}

\subsection{Sampling of fishes}

Fishes to be screened for cellulolytic symbiotic bacteria were sampled live based on their feeding habits with the help of local fishermen, 
from different fishing harbours along the coasts of India and identified based on Fish Identification at fishbase,version(01/2010) (Froese and Pauly, 2010). Five healthy fishes of each species were transported live to the nearest laboratory under sterile conditions and were anaesthetized using clove oil (3-4 ppm) before further processing.

\subsection{Sampling for bacteria}

Screening of cellulose utilizing symbiotic bacteria were carried out under aseptic surroundings. Before dissection, the ventral surface of the fish was thoroughly scrubbed with $1 \%$ iodine solution (Trust and Sparrow, 1974). The fish were dissected within laminar air flow cabinet on ice and the alimentary canals were removed as quickly as possible. Portions of the alimentary canal were first cleaned, then cut into pieces and slit open by a longitudinal incision. The contents were transferred to sterile petridishes. The pieces of the alimentary canal were thoroughly flushed with sterile chilled saline (ph 7.4; 0.89\% (w/v) sodium chloride) and homogenized in sterile saline (10:1; volume: weight) (Das and Tripathi, 1991). The homogenate was used as inoculum for culture. The homogenate of the gut of each of the test fish was subjected to 1:10 serial dilutions.

\subsubsection{Isolation and culture of cellulolytic bacteria from fish gut}

The homogenate of the gastrointestinal wall mucosa of each of the test fish after five-fold serial dilution was used for isolation and enumeration of cellulose utilizing bacteria (Beveridge and Graham, 1991). $0.1 \mathrm{ml}$ sample was taken from each dilution and plated aseptically onto Dubos cellulose Agar media (Composition $\left(\mathrm{g}^{-1}\right)$ ); Carboxymethyl cellulose, 12; $\mathrm{KH}_{2} \mathrm{PO}_{4}, 10 ; \mathrm{NaNO}_{3}, 0.5 ; \mathrm{MgSO}_{4} \cdot 7 \mathrm{H}_{2} \mathrm{O}, 0.5 ; \mathrm{KCl}, 0.5$; $\mathrm{Fe}_{2}\left(\mathrm{SO}_{4}\right)_{3} \cdot 7 \mathrm{H}_{2} \mathrm{O}, 0.004$; Agar, 20 (ph 6). These culture plates were incubated at $35^{\circ} \mathrm{c}$ for $48 \mathrm{~h}$. After appearance of the colonies, the plates were flooded with $5 \mathrm{ml}$ of Congo Red dye prepared in $0.7 \%$ Agarose (Seakem HGT Agarose, Cambrex India Pvt. Ltd., Mumbai, India) according to the method of Teather and Wood (1982). The appearance of a clear zone around the colony after flooding the plates indicated the presence of cellulolytic activity. The discrete and well isolated bacterial colonies on the above mentioned media plates with cellulolytic activities were selected and streaked separately onto nutrient agar plates to obtain pure cultures. Single, isolated colonies from the streaked plates were transferred to nutrient agar slants (supplemented with $2 \%$ nacl) (Composition $\left(\mathrm{g}^{-1}\right)$ ) Peptone -5 ; Meat extract -1 ; Yeast extract -2 ; Sodium chloride - 5; Agar - 15 (ph 7) and stored under refrigerated condition for further studies.

\subsection{Phenotypic characterization of symbiotic bacteria}

The bacterial cultures were identified according to their Phenotypic (morphological, physiological, biochemical) characteristics (Boone and Castenholz, 2001).

\section{Genotypic characterization}

\subsection{Amplification, cloning and sequencing of $16 S$ rRNA gene}

The genomic DNA obtained by denaturation and further centrifugation of bacterial cell was used as the template for PCR to amplify the 16S rRNA gene sequence. PCR primers were used to amplify the 16srRNA gene providing the phylogenetic information. The most common universal primer pair is currently referred to $27 \mathrm{~F}$ and $1492 \mathrm{R}$ (James, 2010). At the end of the PCR run the tube was taken out and electrophoreses of the product was done using Agarose gel electrophoresis. Afterwards the bands of DNA were recovered from the gel by gel extraction and used for cloning. The PCR amplified products were cloned into pGEM-T vector and then sequenced at SciGenom Labs Pvt Ltd, Kochi. DNA samples were sequenced by the sequencing instrument MACROGEN 3730XL7-16112-010 and the sequences were processed by ABI 1.6.0. The sequence were merged in EMBOSS Merger.

\subsection{Phylogenetic analysis}

The 16SrRNA gene sequences were aligned and compared with other 16SrRNA gene sequences in the Genbank by using the NCBI Basic Local Alignment Search Tool, BLASTn program(http://www.ncbi.nlm. nih.gov/BLAST). The E-value was kept at zero for maximum accuracy. The phylogenetic trees were created using homology and phylogenetic analysis by neighbour joining method using multiple sequence alignment program, clustalw with bootstrap replications corresponding to 1000 resamples (Larkin et al., 2007).

\subsection{Sequences deposited in genbank}

The 16SrRNA gene sequences have been deposited to Genbank using BankIt submission tool and has been assigned with Genbank Accession numbers by NCBI.

\subsection{Analysis of GC content}

GC-content is the percentage of nitrogenous bases on a DNA molecule that are either guanine or cytosine from a possibility of four different ones, including adenine and thymine. The GC contents of 16SrRNA genes were calculated based on 16SrRNA gene sequences using Oligo Calculator version 3.26 (Kibbe, 2007).

\section{Utilization of cellulose by the symbiotic bacteria}

\subsection{Bacterial species}

Four cellulolytic bacterial isolates from marine fishes were used for the study. They were Bacillus subtilis strain TCPC1 Carangoides praeustus (Bennett, 1830), Vibrio alginolyticus strain CFSS2C2 from Filimanus similis Feltes, 1991, Pseudomonas stutzeri strain KSLS4C3 from Sardinella longiceps Valenciennes, 1847, and Klebsiella oxytoca strain MSSC4 from Sillago sihama (Forsskål, 1775).

\subsubsection{Seed culture of selected bacteria}

To prepare the seed culture for inoculation, the bacterial isolates stored at $4{ }^{\circ} \mathrm{C}$ on nutrient agar slants were cultured in nutrient broth for $24 \mathrm{~h}$ and were further inoculated to the selective media.

\subsubsection{Media composition}

Nutrient broth $\left(\mathrm{gl}^{-1}\right)$ : Peptone, 10; Meat extract, 10; Sodium chloride, 5; Distilled water, $1000 \mathrm{ml}(\mathrm{pH} 7.2 \pm 0.2)$

Dubo's Cellulose broth ( $\mathrm{g} \mathrm{l}^{-1}$ ): Carboxymethyl cellulose, $12 ; \mathrm{KH}_{2} \mathrm{PO}_{4}$, 10; $\mathrm{NaNO}_{3}, 0.5 ; \mathrm{MgSO} 4 \cdot 7 \mathrm{H}_{2} \mathrm{O}, 0.5 ; \mathrm{KCl}, 0.5 ; \mathrm{Fe}_{2}\left(\mathrm{SO}_{4}\right)_{3} \cdot 7 \mathrm{H}_{2} \mathrm{O}, 0.004$; Agar, 20 (pH 6)

\subsubsection{Innoculum size and sampling}

$0.2 \mathrm{ml}$ innoculum $(0.5 \mathrm{~A}$ at $600 \mathrm{~nm})$ were innoculated to $20 \mathrm{ml}$ cellulose broth. Triplicates were incubated at $37^{\circ} \mathrm{C}$ at an initial $\mathrm{pH}$ of 6.5 for cellulose broths respectively. Sampling was done starting from $18 \mathrm{~h}$ of incubation to 11 days for cellulose utilization to get a clear profile of cellulase production by the selected strains.

\subsection{Utilization of cellulose by the symbiotic bacteria}

The end products of cellulose hydrolysis were determined by Dinitrosalicylic acid (DNSA) method (Denison and Koehn, 1977). Cellulose is broken down to glucose by the enzyme cellulose.

\subsubsection{Cellulose utilization}

DNSA, which acts as a terminating agent to stop the enzyme substrate reaction, was prepared before start of the experiment and kept at 
$4^{\circ} \mathrm{C}$.

\subsubsection{Glucose standard}

Working solution of concentration $1 \mathrm{mg}$ glucose $\mathrm{ml}^{-1}$ was diluted using distilled water in the ratios 2:3, 1:2, 1:3, 1:5 and 1:10. $0.5 \mathrm{ml}$ of each was taken in a test tube. $1 \mathrm{ml}$ distilled water was added and $3 \mathrm{ml}$ DNSA was added and then boiled at $100{ }^{\circ} \mathrm{C}$ for $5 \mathrm{~min}$. It was then cooled in ice bath. Further, OD was measured at $540 \mathrm{~nm}$ against reagent blank. Standard curve was plotted taking concentration of glucose on $x$ - axis and OD on $y$ - axis.

\subsubsection{Preparation of sample for glucose estimation}

To study cellulose utilization, $1 \mathrm{ml}$ of sample from each of triplicate flasks were taken in eppendorf tubes and centrifuged at $10,000 \times g$ for $10 \mathrm{~min}$ at $4^{\circ} \mathrm{C}$. At the end of centrifugation, $0.5 \mathrm{ml}$ of the cell free supernatant was taken. $1 \mathrm{ml}$ distilled water was added and then $3 \mathrm{ml}$ DNSA was added to it. It was boiled at $100^{\circ} \mathrm{C}$ for $5 \mathrm{~min}$ and cooled in ice bath. OD was measured at $540 \mathrm{~nm}$. The value was converted and expressed as $\mathrm{mg}$ of glucose per $\mathrm{ml}$ culture.

\subsection{Rate of utilization of cellulose during exponential phase (Waley, 1981)}

The slope of a chord joining the points $\left(\mathrm{Ut}_{1}, \mathrm{t}_{1}\right)$ and $\left(\mathrm{Ut}_{2}, \mathrm{t}_{2}\right)$ on a progress curve of varying concentration against time is $\left(\mathrm{Ut}_{\mathrm{I}}-\mathrm{Ut}_{2}\right) /\left(\mathrm{t}_{1}\right.$ $\mathrm{t}_{2}$ ), and this slope is equal to the rate,

$\mathrm{R}=\mathrm{Ut}_{2}-\mathrm{Ut}_{1}$

\begin{tabular}{ll}
\hline & $\mathrm{t}$ \\
Where, $\mathrm{t}$ & $-\mathrm{t}_{2}-\mathrm{t}_{1}$ \\
$\mathrm{U} \mathrm{t}_{1}$ & - utilization of cellulose at $\mathrm{t}_{1}$ \\
$\mathrm{U} \mathrm{t}_{2}$ & - utilization of cellulose at $\mathrm{t}_{2}$ \\
$\mathrm{t}_{1}$ & - initial time \\
$\mathrm{t}_{2}$ & - final time \\
\hline
\end{tabular}

\subsection{Statistical analyses}

The data obtained were subjected to analysis of variance (ANOVA) using SPSS data editor and significance at $(P<0.05)$ was determined. Duncans Multiple range test (Duncan, 1955) was done for comparison of performances by testing differences among means. The significance of differences was tested at the significance level $P=0.05$ (Tables 1 and 2).

\section{Results}

The species identified from Carangoides praeustes showed Bacillus subtilis MF-2 as the nearest neighbour (Fig. 1 and Table 3). The strain was designated as Bacillus subtilis strain TCPC1. It was gram positive, translucent, rodshaped and resistant to penicillin. The species identified from Filimanus similis showed Vibrio alginolyticus CAIM 1774 as the nearest neighbour (Fig. 2 and Table 3). The strain was designated as
Vibrio alginolyticus strain CFSS2C2 and was gram negative, translucent, rodshaped and resistant to penicillin. The species identified from Sardinella longiceps showed Pseudomonas stutzeri SS13 as the nearest neighbour (Fig. 3 and Table 3). The strain was designated as P.stutzeri strain KSLS4C3. It was gram negative, opaque, rodshaped and resistant to penicillin. The species identified from Sillago sihama showed Klebsiella oxytoca strain AIMST 10. Pl.3 as the nearest neighbour (Fig. 4 and Table 3). The strain was designated as Klebsiella oxytoca strain MSSC4. It was gram negative, translucent, rodshaped and resistant to penicillin. Table 4

The results obtained for cellulose utilization by different bacterial strains are shown in Figs. 5-8. Cellulolytic activity was the maximum for $B$. subtilis strain TCPC1 $\left(0.45 \mathrm{mg}\right.$ glucose $\left.\mathrm{ml}^{-1}\right), V$. alginolyticus strain CFSS2C2 $\left(0.24 \mathrm{mg}\right.$ glucose $\left.\mathrm{ml}^{-1}\right)$ at $234 \mathrm{~h}$ while $P$. stutzeri strain KSLS4C3 $\left(0.22 \mathrm{mg}\right.$ glucose $\left.\mathrm{ml}^{-1}\right)$ showed the maximum utilization from 240 to $258 \mathrm{~h}$. $K$. oxytoca strain MSSC4 $\left(0.47 \mathrm{mg}_{\left.\text {glucose } \mathrm{ml}^{-1}\right)}\right.$ showed three peaks.

In case of cellulose utilization, the study was conducted for more days because the strains in general showed increase in utilization of cellulose only after $120 \mathrm{~h}$. The cellulose utilization by $P$. stutzeri strain KSLS4C3 and $K$. oxytoca strain MSSC4 showed more than one peak during the study.

The colors of the graphs indicate feeding habits of the fishes from which the particular symbiont was isolated, viz., red colour indicates a marine carnivorous fish, blue indicates a planktivore and black, an omnivorous fish species.

\section{Discussion}

Occurrence of cellulolytic Bacillus spp. And Vibrio sp. In the carnivorous fishes $C$. Praeustus, and F. Similisis noteworthy and indicates the multiple role of bacterial symbionts in GI tract of fish. In a study done with carnivorous fishes, Bairagi et al. (2002) failed to detect cellulolytic bacteria in the gastrointestinal tract of catfish and murrels. However, the result of some other investigations showed the presence of cellulolytic bacteria in carnivorous fishes (Kar et al., 2008; Sugita et al., 1997; Ghosh et al., et al., 2002). Stickney and Shumway (1974) had opined that omnivores and carnivores might pick up cellulolytic flora from the invertebrates that harbour the bacteria. Carnivores may get these from environment or from feed like crustaceans, mollusks or even other fishes they eat. These bacteria may have other functions also to serve than cellulose hydrolysis which they may exhibit under favourable conditions for thriving in a carnivore's gut. The presence of these bacteria in carnivores shows the environmental effect on the gut microflora.

The results also show that omnivorous $S$. sihama harboured the cellulolytic Klebsiella sp. In its gut.B. subtilis has previously been reported in the intestinal tract of flathead grey mullet, mugilcephalusl. (Nagvenkar et al., 2006). Omnivores also obtain their share of symbionts from water and food. As the food of these fishes contain more cellulose matter than that of carnivores, these bacteria can survive in a better way in omnivore's gut. They may aid in digestion of plant matter; thereby increasing the adaptability of the fish to a wide range of feed stuffs for an omnivorous habit.

Table 1

Details of the marine fishes selected for the present study.

\begin{tabular}{|c|c|c|c|c|c|c|c|}
\hline Sl.no & Place & $\begin{array}{l}\text { Location (Latitude and } \\
\text { Longitude) }\end{array}$ & Period & Fish species selected & Feeding habit & $\begin{array}{l}\text { Bacterial } \\
\text { amylolysis }\end{array}$ & $\begin{array}{l}\text { Bacterial } \\
\text { cellulolysis }\end{array}$ \\
\hline 1 & Tuticorin & $8^{\circ} 48^{\prime} \mathrm{N} 8^{\circ} 07^{\prime} \mathrm{E}$ & June 2009 & $\begin{array}{l}\text { Carangoides praeustus (Bennett, } \\
\text { 1830) }\end{array}$ & carnivore & + & + \\
\hline 2 & Calicut & $11^{\circ} 25^{\prime} \mathrm{N} 75^{\circ} 77^{\prime} \mathrm{E}$ & November 2009 & Filimanus similis Feltes, 1991 & carnivore & + & + \\
\hline 3 & Kanyakumari & $8^{\circ} 4^{\prime} \mathrm{N} 77^{\circ} 34^{\prime} \mathrm{E}$ & July 2009 & $\begin{array}{l}\text { Sardinella longiceps Valenciennes, } \\
1847 .\end{array}$ & Phytoplanktivore & + & + \\
\hline 4 & Mandapam & $9^{\circ} 18^{\prime} \mathrm{N} 79^{\circ} 6^{\prime} \mathrm{E}$ & March 2008 & Sillago sihama (Forsskål, 1775). & omnivore & - & + \\
\hline
\end{tabular}


Table 2

Phenotypic characterization of cellulose utilizing bacterial isolates.

\begin{tabular}{|c|c|c|c|c|c|}
\hline S1.no. & Name of test & Carangoides praeustus & Filimanus similis & Sardinella longiceps & Sillago sihama \\
\hline 1 & gram's stain & $\operatorname{Gram}(+)$ & Gram(-) & Gram(-) & $\operatorname{Gram}(-)$ \\
\hline 2 & cell shape & Rods & Short Rods & Rods & Long Rods \\
\hline 3 & appearance & Transluscent & Transluscent & Opaque & Transluscent \\
\hline 4 & elevation & Raised & convex & Umbonate & Convex \\
\hline 5 & margin & Entire & entire & Undulate & Entire \\
\hline 6 & configuration & Round & Round & Round & Round \\
\hline 7 & colour & Off white & Off white & Off white & White \\
\hline 8 & $\mathrm{H}_{2} \mathrm{~S}$ production & + & - & - & - \\
\hline 9 & Mac Conkey agar test & Lactose fermenting & No Growth & Lactose fermenting & Non Lactose fermenting \\
\hline 10 & fluorescence & - & - & - & - \\
\hline 11 & motility & Motile & Non Motile & Motile & motile \\
\hline 12 & catalase & + & + & + & + \\
\hline 13 & oxidase & - & + & + & - \\
\hline 14 & indole & - & - & - & - \\
\hline 15 & MR & + & - & - & + \\
\hline 16 & VP & + & - & - & - \\
\hline 17 & citrate utilization & + & + & + & + \\
\hline 18 & $\mathrm{O} / \mathrm{F}$ test & Fermentative & Fermentative & Alkaline & Fermentative with gas \\
\hline 19 & nitrate reduction & $+(\mathrm{Gas})$ & + & $+(\mathrm{Gas})$ & + \\
\hline 20 & pencilin sensitivity & Resistant & Resistant & Resistant & Resistant \\
\hline 21 & gelatin liquifaction & + & - & + & + \\
\hline 22 & starch utilization & - & + & + & - \\
\hline 23 & cellulose hydrolysis & + & + & + & + \\
\hline 24 & heat resistance & - & - & - & + \\
\hline 25 & growth on $0 \% \mathrm{NaCl}$ & + & + & + & + \\
\hline 26 & growth on $5 \% \mathrm{NaCl}$ & + & + & + & + \\
\hline 27 & growth on $9 \% \mathrm{NaCl}$ & + & + & - & + \\
\hline 28 & growth on $12 \% \mathrm{NaCl}$ & - & - & - & + \\
\hline 29 & growth on $15 \% \mathrm{NaCl}$ & - & - & - & - \\
\hline 30 & growth on $20 \% \mathrm{NaCl}$ & - & - & - & - \\
\hline 31 & growth at $\mathrm{pH} 5.0$ & + & + & - & + \\
\hline 32 & growth at $\mathrm{pH} 9.0$ & + & + & + & + \\
\hline 33 & growth at $\mathrm{pH} 10.0$ & + & + & + & + \\
\hline 1 & adonitol & - & - & - & - \\
\hline 2 & arabinose & $+(G)$ & + & + & - \\
\hline 3 & cellobiose & $+(G)$ & + & + & + \\
\hline 4 & dulcitol & - & - & - & - \\
\hline 5 & fructose & $+(G)$ & + & + & - \\
\hline 6 & glucose & $+(\mathrm{G})$ & + & - & - \\
\hline 7 & inositol & - & - & + & + \\
\hline 8 & lactose & $+(G)$ & - & + & + \\
\hline 9 & mannitol & $+(\mathrm{G})$ & + & - & + \\
\hline 10 & mellibiose & $+(G)$ & - & + & - \\
\hline 11 & raffinose & $+(G)$ & - & + & - \\
\hline 12 & rhamnose & $+(G)$ & - & - & - \\
\hline 13 & salicin & - & - & + & + \\
\hline 14 & sorbitol & $+(G)$ & - & - & - \\
\hline 15 & sucrose & $+(G)$ & + & + & + \\
\hline 16 & trehalose & $+(G)$ & + & + & + \\
\hline 17 & xylose & $+(\mathrm{G})$ & + & + & + \\
\hline \multicolumn{2}{|c|}{ Bacterial genus identified } & Bacillus & Vibrio & Pseudo-monas & Klebsiella \\
\hline
\end{tabular}

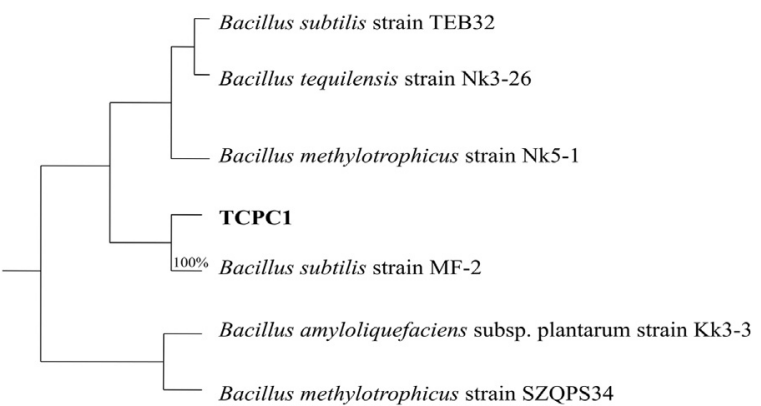

Fig. 1. Phylogenetic tree for TCPC1.

According to the present study, S. Longiceps, a phytoplankton grazer harboured Pseudomonas sp. which was cellulolytic. In planktivores also, the source of symbionts is the environment. These bacterial symbionts may play a more important role in digestion in herbivorous fishes by producing cellulose than in fishes of other feeding habits. In a recent study, Bacillus subtilis cy5 and Bacillus circulans tp3, isolated from the gastrointestinal tracts of Cyprinus carpio and Oreochromis mossambicus respectively were identified as potent cellulase producers (Ray et al., 2007). In case of terrestrial plant/herbivore relationships plant composition has fiber which may be defined as material resistant to endogenous digestion (Cummings and Macfarlane, 1991). In contrast, marine algae contain a complex array of cell wall and storage polysaccharides, and the relationship of these to fish digestive processes is poorly understood (Choat and Clements, 1998). Herbivorous fish may have adapted to these complex algal diets in several ways, including high food intake and gut throughput rates, optimization of key digestive enzymes, and various degrees of reliance on microbial processes in the gut (Mountfort et al., 2002). Since fishes cannot produce cellulases, the digestion of whatever cellulose comes in gut is by these bacteria.

The strains identified in the present study are all new ones which were not previously reported from any source. Bacillus cereus isolated from fish gut was shown to produce protease by Esakkiraj et al. (2009). 
Table 3

Genotypic characterization by $16 \mathrm{~S}$ rRNA gene sequence alignment tools.

\begin{tabular}{|c|c|c|c|c|c|c|c|}
\hline S1. No & Test species & GC content & Nearest neighbour by BLAST & Max.ident. & $\begin{array}{l}\text { GC content of } \\
\text { neighbour }\end{array}$ & Species & $\begin{array}{l}\text { GenBank accession } \\
\text { no: }\end{array}$ \\
\hline 1 & TCPC1 & $55 \%$ & Bacillus subtilis strain MF-2 & $100 \%$ & $55 \%$ & Bacillus subtilis strain TCPC1 & JN710380 \\
\hline 2 & CFSS2C2 & $55 \%$ & $\begin{array}{l}\text { Vibrio alginolyticus strain CAIM } \\
1774\end{array}$ & $99 \%$ & $54 \%$ & $\begin{array}{l}\text { Vibrio alginolyticus strain } \\
\text { CFSS2C2 }\end{array}$ & JN710378 \\
\hline 3 & KSLS4C3 & $52 \%$ & Pseudomonas stutzeri strain SS13 & $98 \%$ & $53 \%$ & $\begin{array}{l}\text { Pseudomonas stutzeri strain } \\
\text { KSLS4C3 }\end{array}$ & JN710377 \\
\hline 4 & MSSC4 & $55 \%$ & $\begin{array}{l}\text { Klebsiella oxytoca strain AIMST } \\
\text { 10.P1.3 }\end{array}$ & $99 \%$ & $56 \%$ & Klebsiella oxytoca strain MSSC4 & JN712301 \\
\hline
\end{tabular}

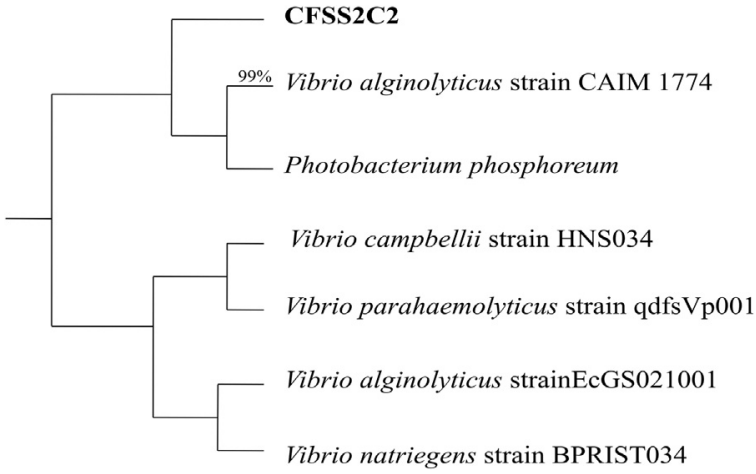

Fig. 2. Phylogenetic tree for CFSS2C2.

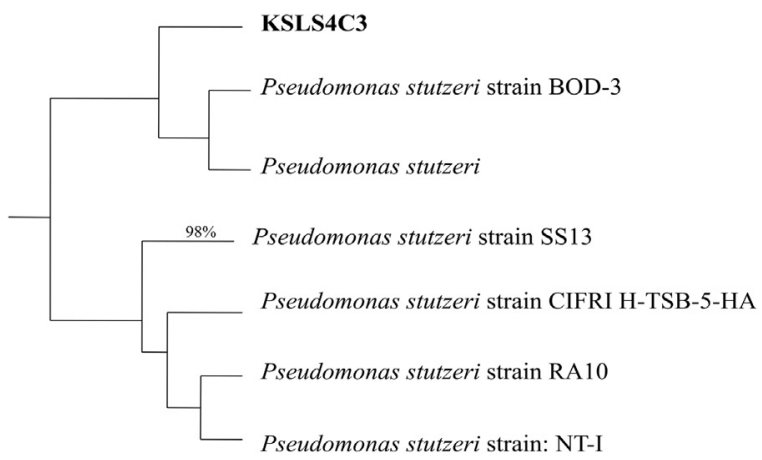

Fig. 3. Phylogenetic tree for KSLS4C3.

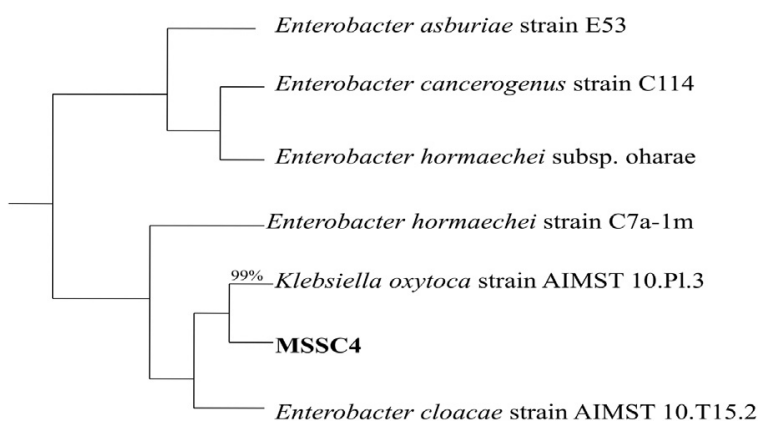

Fig. 4. Phylogenetic tree for MSSC4.

Vibrio alginolyticus has been reported from fish gut (Baross and Liston, 1970; Sun et al., 2009). Pseudomonas stutzeri has been reported from marine environment and fish gut by Lalucat et al. (2006). Aeromonas hydrophila has been reported from marine fish by Larsen and Jensen (1977). Klebsiella oxytoca has been reported from the gut of African cat fish by Oladosu-Ajayi et al. (2011). The scanty references available show the least quantum of work done in gut microbes of marine fishes compared to that in other fields. Molecular methods make it possible to identify new microbes from any source. 16S rRNA gene sequence
Table 4

Rate of cellulose utilization of cellulose by each species at exponential stage of growth.

\begin{tabular}{lll}
\hline S1. No. & Species & $\begin{array}{l}\text { Rate }\left(\mathbf{m g} \text { glucose } \mathbf{~ m l}^{-\mathbf{1}} \text { medium }\right. \\
\left.\mathbf{h}^{-\mathbf{1}}\right)\end{array}$ \\
\hline 1 & Bacillus subtilis strain TCPC1 & 0.002 \\
2 & Vibrio alginolyticus strain CFSS2C2 & 0.001 \\
3 & Pseudomonas stutzeri strain & 0.049 \\
& KSLS4C3 & \\
4 & Klebsiella oxytoca strain MSSC4 & 0.027 \\
\hline
\end{tabular}

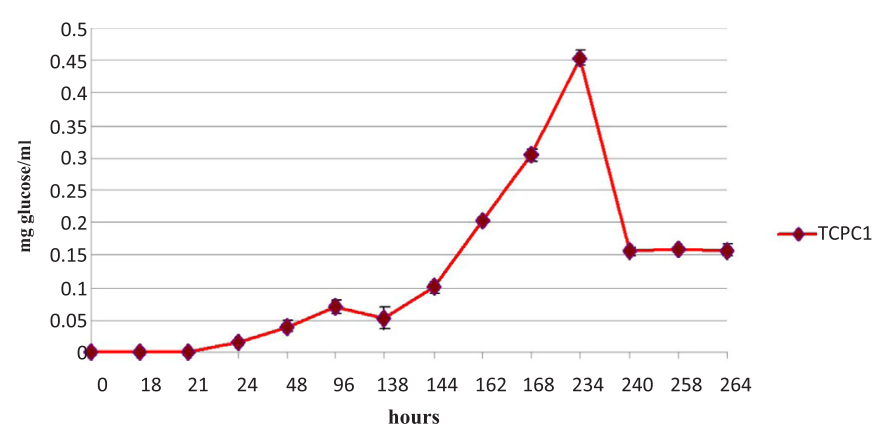

Fig. 5. Cellulose utilization by Bacillus subtilis strain TCPC1.

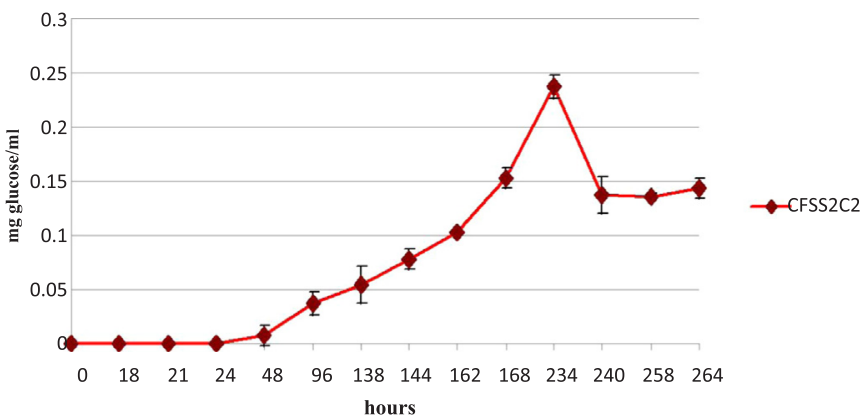

Fig. 6. Cellulose utilization by Vibrio alginolyticus strain CFSS2C2.

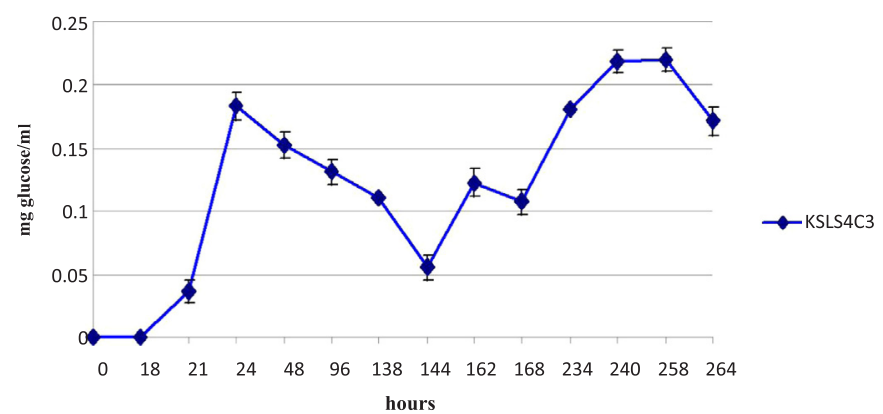

Fig. 7. Cellulose utilization by Pseudomonas stutzeri strain KSLS4C3. 


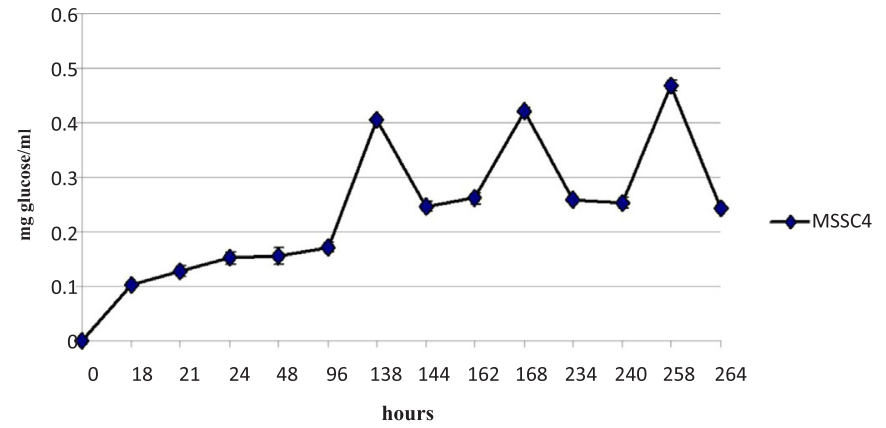

Fig. 8. Cellulose utilization by Klebsiella oxytoca strain MSSC4.

analysis can better identify poorly described, rarely isolated, or phenotypically aberrant strains. Few other genes are as highly conserved as the $16 \mathrm{~S}$ rrna gene. Although the absolute rate of change in the $16 \mathrm{~S}$ rrna gene sequence is not known, it does mark evolutionary distance and relatedness of organisms (Kimura, 1980; Pace, 1997; Thorne et al., 1998; Harmsen and Karch, 2004).

Although 500 and $1500 \mathrm{bp}$ are common lengths to sequence and compare, sequences in databases can be of various lengths. Genbank, the largest databank of nucleotide sequences, has over 20 million deposited sequences, of which over 90,000 are of 16S rRNA gene. This means that there are many previously deposited sequences against which to compare the sequence of an unknown strain (Clarridge, 2004).

The 16S rRNA gene is universal in bacteria, and so relationships can be measured among all bacteria (Woese et al., 1985; Woese, 1987). In general, the comparison of the 16S rRNA gene sequences allows differentiation between organisms at the genus level across all major phyla of bacteria, in addition to classifying strains at multiple levels, including what we now call the species and subspecies level. Sometimes sequencing the entire 1500 -bp region is necessary to distinguish between particular taxa or strains (Sacchi et al., 2002, 2002a2002a, 2002b). Sequencing of the entire 1500-bp sequence is also desirable and usually required when describing a new species. In this study, full length sequences of 16S rRNA gene was used for Klebsiella sp. MSSC4 and partial sequences were used for others which ranged from 600 to 800 base pairs. However, for most clinical bacterialisolates the initial 500-bp sequence provides adequate differentiation for identification and in fact can provide a bigger percent difference between strains because the region shows slightly more diversity per kilobase sequenced. Kattar et al. (2001) found that $66 \%$ of the variability in the $16 \mathrm{~S}$ rRNA gene sequence among Bordetella species was in the first $500 \mathrm{bp}$. Evaluations published in the literature, made using the microseq database (AppliedBiosystems Inc. [ABI], Foster City, Calif.), are usually based on the 500-bp sequence (Tang et al., 1998; 1998, 2000; Patel et al., 2000; TangHall et al., 2000; Hall, et al., 2003). Other researchers have made identifications using sequences of about $400 \mathrm{bp}$ (Bosshard et al., 2003) or even less than 200 bp (Wilck et al., 2001).

The strains under present study after phylogenetic tree preparation were identified as Bacillus subtilis strain TCPC1, Vibrio alginolyticus strain CFSS2C2, Pseudomonas stutzeri strain KSLS4C3 and Klebsiella oxytoca strain MSSC4. The phylogenetic analysis revealed several unresolved relationships between bacterial isolates from the present experiment and their type strain matches. Failure to differentiate closely related species could be due to the fact that full length of the 16S rDNA were used in the present study and that different species of Bacillus, and Klebsiella are very closely related to each other or their phylogeny may be improved further with time as more data is available in public data banks. Though at present this is the latest available method for identification of bacteria, additional characterization methods should be devised if further clarification or fine differentiation is required.

Despite its accuracy, 16S rRNA gene sequence analysis lacks widespread use beyond the large and reference laboratories because of technical and cost considerations. Thus, a future challenge is to translate information from 16S rRNA gene sequencing into convenient biochemical testing schemes, making the accuracy of the genotypic identification available to the smaller and routine clinical microbiology laboratories (Clarridge, 2004).

Pseudomonas stutzeri has been reported to produce amylase (Fujitha et al., 1989; Morishita et al., 1997; Mezaki et al., 2001; Janecek et al., 2003). Reports of cellulose utilizing bacteria from marine fish GI tracts are very rare. Many factors could affect the amount of polysaccharide utilized by endosymbionts in the gut, including accessibility of cell wall polysaccharides in the gut of algal-feeding fish (Mackie et al., 1996).

In the case of cellulose utilization, the bacteria, $K$. oxytoca isolated from omnivorous fish $S$. sihama showed the maximum while all others recorded lower values. Also the maximum production was attained faster by this species than all others. But the maximum rate of utilization at the exponential stage of growth was shown by symbiont $P$. stutzeri from planktivorous fish $S$. longiceps. The cellulose utilization by $P$. stutzeri strain KSLS4C3 and K. oxytoca strain MSSC4 showed more than one peak during the study. This can be attributed to various cycles of bacterial growths being completed in the given time. That is, the bacteria completes one cycle of growth which includes the typical lag phase, exponential phase and death phase in short durations so that various peaks of glucose production by cellulose utilization are obtained within the given time. In case of those showing more than one peak, it is observed that the maximum rate of cellulose utilization is reached earlier than others and they complete two or three cycles of growth while the slower ones could only complete one cycle of growth in the given time. It should be noted that in this respect, the strains which were more active were those obtained from planktivore and omnivorous fishes, while the slower ones were from carnivorous species.

Also, glucose is always metabolized first in preference to other sugars. Glucose represses the induction of inducible operons by inhibiting the synthesis of cyclic AMP (cAMP), a nucleotide that is required for the initiation of transcription of a large number of inducible enzyme systems including the lac operon. Glucose is known to repress a large number of inducible enzymes in many different bacteria. As a form of catabolite repression, the glucose effect serves a useful function in bacteria: it requires the cells to use the best available source of energy. For many bacteria, glucose is the most common and readily utilizable substrate for growth. Thus, it inhibits indirectly the synthesis of enzymes that metabolize poorer sources of energy (Todar, 2011). There is also a chance that, when glucose is produced by cellulose catabolism, the bacteria may utilize this glucose for some time and when the level of glucose again reduces, it starts metabolizing cellulose again and this cycle goes on giving different peaks for glucose production. Also, it shows that if other energy sources are available, a potential cellulase producer may not utilize cellulose, but may utilize easily available sources.

Identification of novel strains of bacteria from unconventional sources always helps in improving the existing technology. Marine environment which encompasses about $71 \%$ of the earth's surface is an important source of unexplored useful enzymes while most of the industrial enzymes are derived from terrestrial sources. Considering the microbial diversity of marine environment, the efforts channeled to discover novel enzymes from marine microbes are inadequate (Mohapatra et al., 2003). Intensive screening attempts alone can lead to unveiling the rich treasure of novel enzymes from marine environment. The strains identified in this study are previously not reported and their enzyme producing ability can be utilized for enzyme biotechnology, biofuel production, animal feed industry and waste management using submerged or solid state fermentation techniques. The prospective probiotic nature of these strains can be investigated and used in aquafeeds for marine fishes.

The ability of the bacteria to utilize cellulose in vitro does not indicate that it is actively involved in digestion of food in fish gut. Further 
studies are required to establish it. Availability of substrate, $\mathrm{pH}$, inhibitors etc. can have detrimental influence on the utilization of cellulose by the symbionts found in marine fish gut. The chemical composition of the diet will also affect the activity of microbes. Only under the influence of given conducive environment, the microbes are expected to exhibit their enzymatic properties up to the maximum potential. Chances are there that, same species of bacteria when found in a herbivore may be actively digesting plant matter, while in a carnivore, it may be proteolytic. In some cases, metabolites or substrates can turn on inactive genes so that they are transcribed. In the process of enzyme induction, the substrate, or a compound structurally similar to the substrate, evokes the formation of enzymes which are usually involved in the degradation of the substrate. Enzymes that are synthesized as a result of genes being turned on are called inducible enzymes and the substance that activates gene transcription is called the inducer. Inducible enzymes are produced only in response to the presence of their substrate and, in a sense, are produced only when needed. In this way the cell does not waste energy synthesizing unneeded enzymes (Todar, 2011).

For animals with variety of diets, diet-related plasticity of endogenous digestive enzyme activity can be explained by the "adaptive modulation hypothesis". It states that variation in diet should confer upon the ability of animals to modulate their digestive enzyme activity accordingly (Karasov, 1992). Modulation of animal digestive enzyme activities in response to diet is common but not universal among vertebrates (Sabat et al., 1999). It has been shown that, fishes with relatively broad diets can modulate digestive enzyme activities in response to changes in dietary composition (German et al., 2004). According to the available literature, such studies have not been done regarding symbiotic bacterial enzymes in fishes. The modulatory enzyme mechanisms with which a bacterial symbiont react to a diet change of the host fish is yet to be studied. The nature and extent of symbiotic relationship between the individual organisms need to be analysed in depth before drawing conclusions based on in vitro experiments.

As a conclusion, it shall be agreed that though in all fishes the bacteria enters into the gut through food and water, the conditions in the gut may be favourable to some of these and they readily colonize the region. However, it is difficult to generalize the relationships between fishes and bacteria as a specific group because of the diverse range of fish species, the environment the fish inhabit and the variety of metabolic requirements of bacteria. They may carry out different functions like proteolysis, starch hydrolysis, cellulose digestion, production of vitamins, general probiotic function etc. This work is first of its kind in a variety of marine fishes and it shows that microbial gut symbionts with ability to utilize cellulose are present in marine carnivores, omnivores and planktivores.

\section{References}

Bairagi, A., Ghosh, K.S., Sen, S.K., Ray, A.K., 2002. Enzyme producing bacterial flora isolated from fish digestive tracts. Aquac. Int. 10, 109-121.

Baross, J., Liston, J., 1970. Occurrence of Vibrio parahaemolyticus and related hemolytic Vibrios in marine environments of Washington State'. Appl. Microbiol. 20 (2), 179-186.

Barrington, E.J.W., 1957. The alimentary canal and digestion. In: Brown, M.E. (Ed.), The Physiology of Fishes 1. Academic Press, New York, pp. 109-161.

Beveridge, T.J., Graham, L.L., 1991. Surface layers of bacteria. Microbiol. Rev. 55 684-705.

Boone, D.R., Castenholz, R.W., 2001. Bacteriology Bergey's Manual of Systematic, 2nd ed. 1 Springer-Verlag, New York, N.Y.

Bosshard, P.P., Abels, S., Zbinden, R., Bottger, E.C., Altwegg, M., 2003. Ribosomal DNA sequencing for identification of aerobic gram-positive rods in the clinical laboratory (an 18-month evaluation). J. Clin. Microbiol. 41, 4134-4140.

Chakrabarti, I., Gani, M.A., Chaki, K.K., Sur, R., Misra, K.K., 1995. Digestive enzymes in 11 freshwater teleost fish species in relation to food habit and niche segregation. Comp. Biochem. Physiol. A 112, 167-177.

Chandrasekaran, M., 1997. Industrial enzymes from marine microorganisms: The Indian Scenario. J. Mar. Biotechnol. 5, 86-89.

Chiu, Y.N., Benitez, L.V., 1981. Studies on the carbohydrases in the digestive tract of the milkfish Chanoschanos. Mar. Biol. 61, 247-254.

Choat, J.H., Clements, K.D., 1998. Vertebrate herbivores in marine and terrestrial environments: a nutritional ecology perspective. Ann. Rev. Ecol. Syst. 29, 375-403.

Clarridge, J.E., 2004. Impact of $16 \mathrm{~S}$ rrna gene sequence analysis for identification of bacteria on clinical microbiology and infectious diseases. Clin. Microbiol. Rev. 17 (4), $840-862$.

Cockson, A., Bourne, D., 1972. Enzymes in the digestive tract of two species of euryhaline fish. Comp. Biochem. Physiol. A 41, 715-718.

Cummings, J.H., Macfarlane, G.T., 1991. The control and consequences of bacterial fermentation in the human colon. J. Appl. Bacteriol. 70, 443-459.

Das, K.M., Tripathi, S.D., 1991. Studies on the digestive enzymes of grass carp, Ctenopharyngodonidella (Val). Aquaculture 92, 21-32.

Denison, D.A., Koehn, R.D., 1977. Assay of cellulases. Mycologia LXIX, 592.

Dhiman, T.R., Zaman, M.S., Gimenez, R.R., Walters, J.L., Treacher, R., 2002. Performance of dairy cows fed forage treated with fibrolytic enzymes prior to feeding. Animal Feed Sci Technol 101, 115-125.

Drewe, K.E., Horn, M.H., Dickson, K.A., Gawlicka, A., 2004. Insectivore to frugivore: ontogenetic changes in gut morphology and digestive enzyme activity in the characid fish Bryconguatemalensisfrom Costa Rican rainforest streams. J. Fish. Biol. 64, 890-902.

Duncan, D.B., 1955. Multiple range and multiple F tests. Biometrics 11, 1-42.

Esakkiraj, P., Immanuel, G., Sowmya, S.M., Iyapparaj, P., Palavesam, A., 2009. Evaluation of protease-producing ability of fish gut isolate Bacillus cereus for Aqua feed. Food Bioprocess Technol. 2 (4), 383-390.

Fenical, W., 1993. Chemical studies of marine bacteria: Developing a new resource. Chem. Rev. 93, 1673-1683.

Fish, G.R., 1951. Digestion in Tilapia esculenta. Nature 167.

Fish, G.R., 1960. The comparative activity of some digestive enzymes in the alimentary canal of tilapia and perch. Hydrobiologia 15, 161-178.

Froese, R. And Pauly, D., Editors. 2010. Fishbase. World Wide Web electronic publication. Fish Identification at fishbase, version $(01 / 2010)\langle w w w$.fishbase.org .

Fujitha, M., Torigoe, K., Nakada, T., Tsusaki, K., Kubota, M., Sakai, S., Tsujisaka, Y., 1989. Cloning and nucleotide sequence of the gene (amyP) for maltotetraose- forming amylase from Pseudomonas stutzeri MO-19. J. Bacteriol. 171, 1333-1339.

German, D.P., Horn, M.H., Gawlicka, A., 2004. Digestive enzyme activities in herbivorous and carnivorous prickleback fishes (Teleostei: Stichaeidae): ontogenetic, dietary, and phylogenetic effects. Physiol. Biochem. Zool. 77, 367-410.

Ghosh, K., Sen, S.K., Ray, A.K., 2002. Characterization of bacilli isolated from gut of rohu, Labeorohita, fingerlings and its significance in digestion. J. Appl. Aquac. 12, 33-42.

Hall, L., Doerr, K.A., Wohlfiel, L.S., Roberts, G.D., 2003. Evaluation of the microseq system for Identification of mycobacteria by $16 \mathrm{~S}$ ribosomal DNA sequencing and its integration into a routine clinical mycobacteriology laboratory. J. Clin. Microbiol. 41, 1447-1453.

Harmsen, D., Karch, H., 2004. 16S rdna for diagnosing pathogens: a living tree. ASM News 70, 19-24.

Horn, M.H., Neighbors, M.A., Murray, S.N., 1986. Herbivore responses to a seasonally fluctuating food supply: growth potential of two Location for James temperate in tertidal fishes based on the protein and energy assimilated from their macroalgal diets. J. Exp. Mar. Biol. Ecol. 103, 217-234.

Janecek, S., Svensson, B., MacGregor, E.A., 2003. Relation between domain evolution, specificity, and taxonomy of the a-amylase family members containing a C-terminal starch-binding domain. Eur. J. Biochem. 270, 635-645.

James, G., 2010. Universal bacterial identification by PCR and DNA sequencing of $16 \mathrm{~S}$ rrna gene. In: PCR for Clinical Microbiology. Springerlink, Dordrecht, pp. 209-214 Part 3.

Kar, N., Ghosh, K., 2008. Enzyme producing bacteria in the gastrointestinal tracts of Labeorohita(Hamilton) and Channapunctatus(Bloch) Turk. J. Fish. Aquat. Sci. 8, $115-120$.

Kar, N.R.N., Roy, S.K., Ghosh, Senand K., 2008. Enzyme producing bacilli in the digestive tracts of rohulabeorohita(Hamilton) and murrelchannapunctatus(bloch). Asian Fish. Sci. 21, 421-434.

Karasov, W.H., 1992. Test of the adaptive modulation hypothesis for dietary control of intestinal transport. Am. J. Physiol. 267, R496-R502.

Kattar, M.M., Chavez, J.F., Limaye, A.P., Rassoulian-Barrett, S.L., Yarfitz, S.L., Carlson, L.C., Houze, Y., Swanzy, S., Wood, B.L., Cookson, B.T., 2001. Application of 16 S rma gene sequencing to identify Bordetellahinzii as the causative agent of fatal septicemia. J. Clin. Microbiol. 38, 789-794.

Kibbe, W.A., 2007. 'Oligocalc: an online oligonucleotide properties calculator'. Nucleic Acids Res. 35 (webserver issue)(May 25).

Kimura, M., 1980. A simple method for estimating evolutionary rates of base substitutions through comparative studies of nucleotide sequences. Mol. Evol. 16, 111-120.

Kobayashi, J., Masami, I., 1993. Bioactive metabolites of symbiotic marine microorganisms. Chem. Rev. 93, 1753-1769.

Krogdahl, A., Hemre, G.I., Andmommsen, T.P., 2005. Carbohydrates in fish nutrition: digestion and absorption in postlarval stages. Aquacult. Nutr. 11, 103-122.

Kuhad, R.C., Gupta, R., Singh, A., 2011. Microbial Cellulases and Their Industrial Applications. Enzyme Res, 10-20.

Lalucat, J., Bennasar, A., Bosch, R., Garcia-Valdes, E., Palleroni, N.J., 2006. Biology of Pseudomonas stutzeri. Microbiol. Rev. 70, 510-547.

Larkin, M.A., Blackshields, G., Brown, N.P., Chenna, R., mcgettigan, P.A., mcwilliam, H., Valentin, F., Wallace, I.M., Wilm, A., Lopez, R., Thompson, J.D., Gibson, T.J., Higgins, D.G., 2007. Clustal W and clustal X version 2.0. Bioinformatics 23, 2947-2948.

Larsen, J.L., Jensen, N.J., 1977. An Aeromonas species implicated in ulcer-disease of the cod (Gadusmorhua). Nord Vet. Med. 29, 199-211.

Lesel, R., Fromageot, C., Lesel, M., 1986. Cellulase digestibility in grass carp, Ctenopharyngodonidella and in gold fish, Carassiusauratus. Aquaculture 54, 11-17.

Lindsay, G.J.H., Harris, J.E., 1980. Carboxymethylcellulase activity in the digestive tract 
of fish. J. Fish. Biol. 16, 219-233.

Luczkovich, J.J., Stellwag, E.J., 1993. Isolation of cellulolytic microbes from the intestinal tract of the pinfish, Lagodonrhornboides size-related changes in diet and microbial abundance. Mar. Biol. 116, 381-388.

Mackie, R.I., Bryan, A.W., Isaacson, R.E., 1996. Gastrointestinal Microbiology: Gastrointestinal Ecosystems and Fermentations. 2. Springer, US, pp. 682

Maki, M., Leung, K.T., Qin, W., 2009. The prospects of cellulase-producing bacteria for the bioconversion of lignocellulosic biomass. Int. J. Biol. Sci. 5, 500-516.

Morishita, Y., Hasegawa, K., Matsuura, Y., Katsube, Y., Kubota, M., Sakai, S., 1997. Crystal structure of a maltotetraose-forming exo-amylase from Pseudomonas stutzeri. J. Mol. Biol. 267, 661-672.

Mezaki, Y., Katsuya, Y., Kubota, M., Matsuura, Y., 2001. Crystallization and structural analysis of intact maltotetraose forming exo-amylase from Pseudomonas stutzeri. Biosci. Biotechnol. Biochem. 65, 222-225.

Mohapatra, B.R., Bapuji, M., Sree, A., 2003. Production of industrial enzymes(amylase, carboxymethylcellulase and protease) by bacteria isolated from marine sedentary organisms. Acta Biotechnol. 1, 75-84.

Moran, D., Clements, K.D., 2002. Diet and endogenous carbohydrases in the temperate marine herbivorous fish Kyphosussydneyanus(Perciformes: Kyphosidae). J. Fish. Biol. 60, 1190-1203.

Mountfort, D.O., Campbell, J., Clements, K.D., 2002. Hindgut Fermentation in three species of marine herbivorous fish. Appl. Environ. Microbiol. 68 (3), 1374-1380.

Murad, M.A., Azzaz, H.H., 2010. Cellulase and dairy animal feeding. Biotechnology 9 , 238-256.

Nagvenkar, G.S., Nagvenkar, S.S., Rivonker, C.U., Sangodkar, U.M.X., 2006. Microbial diversity and enzyme production in mullet mugilcephalusl. (Pisces) along Goa, west coast of India. Indian J. Geo-Mar. Sci. 35 (1), 36-42.

Oladosu-Ajayi, R.N., George, F.O.A., Obasa, S.O., Ajayi, A.A., Bankole, M.O., 2011 Bacterial load, composition and succession in the African catfish Clariasgariepinus (Burchell, 1822) held at ambient temperatures. Researcher 3 (7), 67-73.

Pace, N., 1997. A molecular view of microbial diversity and the biosphere. Science 276, 734-740.

Patel, J.B., Leonard, D.G., Pan, X., Musser, J.M., Berman, R.F., Nachamkin, I., 2000. Sequence-based identification of Mycobacterium species using the Microseq. 500 16S rdna bacterial identification system. J. Clin. Microbiol. 38, 246-251.

Pomponi, S.A., 1999. The bioprocess-technological potential of the sea. J. Biotechnol. 70, $5-13$.

Ramu, C., Hideaki, S., Tadashi, K., Rodrigo, L., Toby, J.G., Desmond, G.H., Julie, D.T., 2003. Multiple sequence alignment with the Clustal series of programsnucl. Acids Res. 31 (13), 3497-3500.

Ray, A.K., Bairagi, A., sarkarghosh, K., Sen, S.K., 2007. Optimization of fermentation conditions for cellulose production by Bacillus subtiliscy5 and Bacillus circulanstp3 isolated from fish gut. Acta. Piscat. 37 (1), 47-53.

Romero, J., Navarrete, P., 2006. 16S rdna-based analysis of dominant bacterial populations associated with early life stages of coho salmon (Oncorhynchuskisutch). Microb. Ecol. 51, 422-430.

Sabat, P., Lagos, J.A., Bozinovic, F., 1999. Test of the adaptive modulation hypothesis in rodents: dietary flexibility and enzyme plasticity. Comp. Biochem. A 123, 83-87.

Sacchi, C.T., Whitney, A.M., Mayer, L.W., Morey, R., Steigerwalt, A., Boras, A., Weyant, R.S., Popovic, T., 2002a. Sequencing of $16 \mathrm{~S}$ rrna gene: a rapid tool for identification of Bacillus anthracis. Emerg. Infect. Dis. 8, 1117-1123.

Sacchi, C.T., Whitney, A.M., Reeves, M.W., Mayer, L.W., Popovic, T., 2002b. Sequence diversity of Neisseria meningitidis 16S rrna genes and use of 16S rrna gene sequencing as a molecular subtyping tool. J. Clin. Microbiol. 40, 4520-4527.

Shcherbina, M.A., Kazlawlene, O.P., 1971. The reaction, of the medium and the rate of absorption of nutrients in the intestine of carp. J. Icthyology 11, 81-85.

Stickney, R.R., Shumway, S.E., 1974. Occurrence of cellulose activity in the stomachs of fish. J. Fish. Biol. 6, 779-790.

Sugita, H., Kawasaki, J., Deguchi, Y., 1997. Production of amylase by the intestinal microflora in cultured freshwater fish. Lett. Appl. Microbiol. 24, 105-108.

Sun, Y., Yang, Hongling, Ling, Zechun, Chang, Jianbo, Ye, Jidan, 2009. Gut microbiota of fast and slow growing grouperepinepheluscoioidesafrican. J. Microbiol. 3 (11), $713-720$.

Tang, Y.W., Ellis, N.M., Hopkins, M.K., Smith, D.H., Dodge, D.E., Persing, D.H., 1998. Comparison of phenotypic and genotypic technique for identification of unusual aerobic pathogenic gram-negative bacilli. J. Clin. Microbiol. 36, 3674-3679.

Tang, Y.W., Von Graevenitz, A., Waddington, M.G., Hopkins, M.K., Smith, D.H., Li, H., Kolbert, C.P., Montgomery, S.O., Persing, D.H., 2000. Identification of coryneform bacterial isolates by ribosomal DNA sequence analysis. J. Clin. Microbiol. 38, 1676-1678.

Tanu, Deobagkar, D.D., Khandeparker, R., Sreepada, R.A., Sanaye, S.V., Pawar, H.B., 2011. A study on bacteria associated with the intestinal tract of farmed yellow seahorse, Hippocampus kuda(Bleeker, 1852): characterization and extracellular enzymes. Aquacult. Res. 42 (4), 1-9.

Teather, R.M., Wood, P.J., 1982. Use of Congo red-polysaccharide interactions in enumeration and characterization of cellulolytic bacteria from the bovine rumen. Appl. Environ. Microbiol. 43, 777-780.

Thorne, J.L., Kishino, H., Painter, I.S., 1998. Estimating the rate of evolution of the rate of molecular evolution. Mol. Biol. Evol. 15, 1647-1657.

Trischman, J., Tapiolas, D.M., Fenical, W., Dwight, R., Jensen, R., 1994. Salinamide A and B antiinflammatory depsipeptides from a marine streptomycete. J. Am. Chem. Soc. 116, 757-758.

Todar, K., 2011. Todar's Online Textbook of Bacteriology. 〈www.textbookofbacteriology. net>.

Trust, T.J., Sparrow, R.A., 1974. The bacterial flora in the alimentary tract of freshwater salmonid fishes. Can. J. Microbiol. 20 (9), 1219-1228.

Ventosa, A., Nieto, J.J., 1995. Biotechnological applications and potentialities of halophilic microorganisms. World J. Microbiol. Biotechnol. 11, 85-94.

Waley, S.G., 1981. An easy method for the determination of initial rates. Biochem. J. 193, 1009-1012.

Wilck, M.B., Wu, Y., Howe, J.G., Crouch, J.Y., Edberg, S.C., 2001. Endocarditis caused by culture-negative organisms visible by Brown and Brenn staining: utility of PCR and DNA sequencing for diagnosis. J. Clin. Microbiol. 39, 2025-2027.

Woese, C.R., 1987. Bacterial evolution. Microbiol. Rev. 51, 221-271.

Woese, C.R., Stackebrandt, E., Macke, T.J., Fox, G.E., 1985. A phylogenetic definition of the major eubacterial taxa. Syst. Appl. Microbiol. 6, 143-151.

Yang, G., Bao, B., Peatman, E., Li, H., Huang, L., Ren, D., 2007. Analysis of the composition of the bacterial community in puffer fish Takifuguobscurus. Aquaculture 262, 183-191.

Yokoi, Y., Yasumasu, I., 1964. The distribution of cellulase in invertebrates. Comp. Biochem. Physiol. 13, 223-228.

Zoetendal, E.G., Collier, C.T., Koike, S., Mackie, R.I., Gaskins, H.R., 2004. Molecula ecological analysis of the gastrointestinal Microbiota: a review. J. Nutr. 134, 465-472. 